\title{
INTRODUCTION: Questions and challenges for civil society and human rights in Asia
}

Edition 6, 2021

Dr Anthony J. Spires

DOI: doi.org/10.37839/MAR2652-550X6.17

Political and social change in Asia since the 1980s has transformed many countries from dictatorships to democracies in a relatively short period of time, further spreading awareness of human rights and the liberatory potential of participatory civic action. Yet, as elsewhere, many societies in Asia have recently witnessed the rapid rise of populists and democratic regression. The struggles faced by human rights activists and the increasingly vocal challenges to a progressive civil society have, arguably, led to a moment of questioning that stretches across much of the region.

Civil society actors concerned with human rights find themselves confronting a set of interrelated puzzles: When does it make political and strategic sense to speak up about abuses? Whose rights are we talking about? Who speaks (up) for whom? In the face of new challenges, what might still work for the promotion of human rights? How do we reconcile global values with local realities?

How civil society and other actors are responding to these dilemmas lies at the heart of this issue of Melbourne Asia Review.

\section{When to speak up?}

As civil society organisations become more experienced and confront changes in 
political realities, they are often challenged to make decisions on when, and how, to speak up about human rights abuses.

Looking at the case of Myanmar, where a recent military coup has effectively deposed a democratically elected government, Jonathan Liljeblad asks why the Myanmar National Human Rights Commission has been virtually silent on the bloodshed and atrocities the world has watched unfold. Is the case of Myanmar the canary in the coal mine for similar human rights institutions in other states, where not taking a public stand may be deemed the wiser course of action? The deaths of over 700 people since February 2021 and the likely enforced disappearances of many others remind us of not only the 'bad old days' of widespread, brutal authoritarian regimes in Asia, but of the continuing struggle to bring to justice the perpetrators of such atrocities (Tae-Ung Baik).

In neighbouring Thailand, another state led by a military regime claiming to be protecting the people against corrupt politicians, Janjira Sombatpoonsiri shines a light on the dark side of online and offline citizens' groups who 'weaponise' the law to shrink the space for democratic debate. In the Philippines, Emerson Sanchez and Jayson Lamcheck unveil the political and moral conundrum faced by left-leaning civil society groups that lent initial support to Duterte only to regret it when his 'war on drugs' became increasingly violent and led to widespread abuses of suspected drug dealers and users.

In Hong Kong, another hot spot of activism in recent years, the former British colony has faced a series of challenges to the fundamental rights of association and expression that its citizens had come to take for granted since the territory was 'handed over' to Beijing in 1997. Taking the case of imprisoned billionaire-turnedactivist Jimmy Lai as an example, Thomas E. Kellogg and Lydia Wong explore how a National Security Law imposed by Beijing in 2020 has been used to not only stifle dissent but to fundamentally alter the popular imagination of what rights are available to Hong Kong people. 
Even in democratic Japan, those who speak up in favour of liberal democratic values have found themselves under attack on social media. In 2015, youth activists protesting against then-Prime Minister Shinzo Abe's imposition of restrictions on free speech and democratic process, while initially finding support in the press, soon became the targets of nationalistic, racialised, and gendered online abuse by rightwing Japanese 'netizens' (Robin O’Day, Satsuki Uno and David Slater).

\section{Whose rights? And who speaks (up) for whom?}

Questions of 'rights for whom' are still debated across the region. In the case of China, where the government denies 'indigenous' status to its 'ethnic minority' groups, local languages are under threat of disappearing by the end of the century (Gerald Roche). In Thailand, claims made by conservative nationalists reveal heated contestation over the implications of human rights 'for all' and the legitimacy of government and conservative civil society groups as representatives of the people (Sombatpoonsiri).

In Australia, who speaks (up) for whom is a question with implications for the country's international credibility on human rights issues but also for its trade and security interests. Criticism of pariah states like North Korea may come easy (Melissa Conley Tyler), but when consequences are real for criticising key trade partners and neighbours in the Asia-Pacific, what guides Australian policymakers?

\section{What might work?}

While finding space for progressive activism seems increasingly difficult, we also find creativity and resilience in unlikely places. In Hong Kong, despite the political turmoil of the past few years, Sophie Chen and Chris Chan show how the timing of the COVID-19 pandemic - coming in the middle of a massive social 
movement-allowed Hong Kong activists to transform networks developed for one purpose into another, mobilising information and resources to help ensure the health of Hong Kong residents at a time when trust in government was negligible.

In Indonesia, ideas about human rights have spread through local artist communities, providing a resource to explore past (and present) environmental traumas and social injustices (Edwin Jurriens). Further afield, many Arab countries, including conflict-ridden states but even new democracies like Tunisia, are finding that public health policy measures ostensibly intended to combat the COVID-19 pandemic have seemingly exacerbated pre-existing inequalities and social disparities (Larbi Sadiki and Layla Saleh).

\section{Global values meet local realities}

Carried aloft by the United Nations and international NGOs, ideals of human rights and civil society participation are global in their scope and ambition. Yet local realities, and resistances, often present obstacles to implementation, even when governments and local NGOs take up the cause.

The rights of people with disabilities, for example, have been enshrined in the United Nations Convention on the Rights of Persons with Disabilities, which the Indian government signed up to in 2008. Yet even after passing a national law to implement the convention locally, Indian civil society organisations still recount a litany of discriminatory practices that pose major obstacles for people with disabilities (Paul Chaney).

In looking at Southeast Asia, the story for LGBT rights is mixed at best, with some queer-identified people subject to criminal prosecution and social persecution. Still, as Meredith Weiss explains, an active caucus within ASEAN is making progress at building solidarity, if not (yet) policy change, among civil society groups concerned with issues of sexual orientation and gender expression. 
How these multiple dilemmas and questions are addressed will determine the future of human rights protections and re-shape the political and social space for civil society action. As the articles collected here reveal, the 'endings' of these stories are still unwritten, yet extremely consequential for the welfare and well-being of people across Asia.

Image: Hong Kong protests, 2019. Credit: Katherine Cheng/Flickr.

Related webinars:

WEBINAR: Human rights and democratic regression in Asia

Transnational civil society in Asia 